\title{
Dialogical relations between public educational policies and technological-pedagogical fluency in teacher training
}

\section{Relaciones dialógicas entre políticas públicas educativas y fluencia tecnológica-pedagógica en la formación de profesores}

\author{
Elena Maria Mallmann \\ Universidade Federal de Santa Maria. Santa María, Brasil \\ elena.ufsm@gmail.com \\ Juliana Sales Jacques \\ Universidade Federal de Santa Maria. Santa María, Brasil \\ juletras.jacques@gmail.com
}

\begin{abstract}
This paper analyzes how educational public policies and Pedagogical Projects of Courses (PPC) on teacher training in Brazil trace parameters for the integration of networked technologies in the curriculum, in order to improve technological and pedagogical fluency in the training process. This research is justified by the fact that media education is seen as essential, and it ensures both teachers trainers and teachers in training the development of skills and competences for citizenship, as subjects who transform their reality in network. It is based on the dialogicalproblematizing Freire education as a matrix for critical analysis of the propositions in public policies as well as feasible and possible educational practices. The methodological procedures of research-action comprised participant observation and discursive textual analysis. The indicators were generated from the mapping of current educational public policies for teacher training at national and institutional levels - respectively, Brazil and the Federal University of Santa Maria (UFSM), locus of the research - and it indicates progress and limit situations for effective media education in higher education. The main scientific results and technological and educational innovations are a diagnosis on the applicability and the impact of public policies in teacher training programs that support and encourage the integration of networked technology in the curriculum of higher education in UFSM. In conclusion, it points to the need for evaluation and continuous deliberation of the PPC in order to expand the integration of networked educational technologies to achieve technological and pedagogical fluency.
\end{abstract}

Keywords

Networked educational technologies, Public policies, Teacher training, Technological and pedagogical fluency, Higher education.

\section{Resumen}

Este artículo analiza cómo las políticas y cursos de Proyecto Pedagógico (PPP) la formación de profesores en Brasil educativos, parametrizar la integración de las tecnologías de red en el plan de estudios, con el fin de mejorar la fluidez tecnológica y pedagógica en el proceso de formación. Esta investigación se justifica en vista de la esencialidad de la educación en medios, asegurando formadores y profesores de formación, desarrollo de habilidades y competencias para el desempeño de la ciudadanía, 
como la realidad de la red de los transformadores de los sujetos. Se basa en la educación de Freire-problematizar dialógica como matriz para el análisis crítico de la encuesta ha sido anunciado en las políticas públicas y factible, posible en las prácticas educativas. Los procedimientos metodológicos de la investigación-acción contemplan la observación participante y análisis del texto discursivo. Los indicadores se generan a partir de la asignación de las políticas educativas actuales para la formación docente a nivel nacional Brasil - e institucional - Universidad Federal de Santa María (UFSM), locus de la investigación - avances y situaciones límite para la educación efectiva de señalización medios de comunicación en la educación superior. Los principales resultados científicos y las innovaciones tecnológicas y educativas son el diagnóstico de la aplicabilidad e impacto de las políticas públicas en la formación de docentes para fomentar e inducir la integración de la tecnología de red en el plan de estudios de educación superior en UFSM. En conclusión, se señala la necesidad de una evaluación continua y la deliberación de la PPC con el fin de ampliar la integración de las tecnologías de la educación en la red para lograr la fluidez tecnológica y pedagógica.

Palabras clave

Las tecnologías de red educativas, Políticas públicas, Formación de profesores, La fluidez tecnológica y pedagógica, Educación superior.

\section{Introduction}

The integration of networked educational technologies in the curriculum of teacher training courses in Brazil is supported by public policies in education. With the innovations of Web 2.0, activities can be developed within the same group of people at different times and spaces. In addition to enhancing communication and interaction, these innovations enable the development of new methods of teaching and learning, based on collaboration, and the enhancement of teachers' performance at different levels of education.

In the light of Freire's dialogical-problematizing education (Freire, 1987, 1996), collaborative production mediated by networked technologies is pointed as a means of knowledge production, given that with the wide access to the information available on the network and to different interaction tools (such as social networks), there has been an increase in the sharing of opinions, ideas and products. Bringing this trend to the field of education, networked technologies can constitute mechanisms of interaction and collaboration to transform information into knowledge.

In other words, it is argued that the contents can be interpreted and critically analyzed, establishing relations with different fields of knowledge. When these actions are put into practice, the ability to evaluate the bias and purpose of information becomes more latent and, therefore, it is possible to diagnose what is useful or not, or how to use such information to our advantage. Thus, in this article, an interpretive-critical analysis of the research results on the impact of public policies in the educational practices is presented, considering the integration of networked educational technologies in teacher training to expand technological and pedagogical fluency (Mallmann, Schneider, Mazzardo, 2013; Kafai and others, 1999) as the current priority of media education in higher education.

\section{Methodological path: from the production of data to the interpretive-critical analysis}

This action-research was developed as an exploratory and explanatory research of the contemporary presence of educational technologies in higher education. The data, derived from observation records, questionnaires and document analyses, were compiled in order to examine how public policies' guidelines and parameters are

Dialogical relations between public educational policies and technological-pedagogical fluency in teacher training. Elena Maria Mallmann y Juliana Sales Jacques 
effectively manifest in the Pedagogical Project of the Course (PPC) and in educational practices at the Education Center of the Federal University of Santa Maria (CE / UFSM). Discursive textual analysis was the analytical technique used for the analyses of the PPC and the National Public Policies for Teacher Training. The compilation of all sources of data follows the principles of triangulation, in which they are complementary and were arranged according to the categories summarized.

Thus, public policies related to the topic of the research were selected and encoded. There were twelve (12) PPC (classroom and distance courses) of undergraduate programs in Education, Special Education and Teacher Training for Professional Education, and the graduate programs of a specialization course in Educational Management, a Professional Master's degree in Networked Educational Technology, and the Master's degree and PhD in Education of the Education Center of UFSM.

The analytical process encompassed three stages, proposed by Moraes and Galiazzi (2006, p. 2): a) unitarization by separating the texts into units. Numbering and encoding of the fragments of each document; b) categorization, by gathering and articulating similar meanings and generating analytical categories; c) communication, for "the proposal is not intended to reproduce the original texts, but to weave a new writing, called metatext, which establishes a relation of coherence with the original texts" (Dalmolin, 2014, p. 45). Systematically, the steps were:

a) classification of documents according to scope;

b) identification of scope classes with the first code;

c) identification of document type with the second code;

d) creation of the third code covering the year of approval of the document. (Table 1).

\section{Chart1}

Document codes.

\begin{tabular}{|c|c|}
\hline REPRESENTATION & DOCUMENT \\
\hline D1_P_04 & Ordinance No. 4,059, of December 10, 2004 \\
\hline D1_D_05 & Decree No. 5.622, of December 19, 2005 \\
\hline D1_D_06 & Decree No. 5800, of June 8, 2006 \\
\hline D1_ED_15 & Notice No. 15_Capes_Fomento ao uso das TIC \\
\hline D2_L_96 & Law No. 9.394, of December 20,1996 \\
\hline D2_D_99 & Decree No. 3.276, of December 6, 1999 \\
\hline D2_R1_99 & Resolution No. 1, of September 30, 1999 \\
\hline D2_R2_99 & CES Resolution No. 2, of May 19, 1999 \\
\hline D2_R1_02 & CNE / CP1 Resolution, of February 18, 2002 \\
\hline D2_R2_02 & CNE / CP2 Resolution, of February 19, 2002 \\
\hline D2_R2_04 & Resolution No. 2, of August 27, 2004 \\
\hline D2_R1_05 & Resolution No. 1, of 17 November 2005 \\
\hline D2_R1_09 & Resolution No. 1, of February 11, 2009 \\
\hline D2_R3_12 & Resolution No. 3, of 7 December 2012 \\
\hline D3_R1_05 & Resolution No. 1, of February 1, 2005 \\
\hline D3_R1-06 & CNE / CP Resolution No. 1, of May 15, 2006 \\
\hline D3_R8_06 & Resolution No. 8, of March 29, 2006 \\
\hline D3_R9_07 & Resolution No. 9, of October 4, 2007 \\
\hline D3_R2_08 & Resolution No. 2, of June 26, 2008 \\
\hline D3_R2_09 & Resolution No. 2, of January 29, 2009 \\
\hline D3_R3_09 & Resolution No. 3, of February 10, 2009 \\
\hline
\end{tabular}

Dialogical relations between public educational policies and technological-pedagogical fluency in teacher training. Elena Maria Mallmann y Juliana Sales Jacques 


\begin{tabular}{|c|c|}
\hline PPD & PPC Daytime Bachelor's Degree in Pedagogy \\
\hline PPN & PPC Evening Bachelor's Degree in Pedagogy \\
\hline PPUAB & PPC Distance Bachelor's Degree in Pedagogy \\
\hline PEED & PPC Daytime Bachelor's Degree in Special Education \\
\hline PEEN & PPC Evening Bachelor's Degree in Special Education \\
\hline PEEUAB & PPC Distance Bachelor's Degree in Special Education \\
\hline PFP & PPC Special Program for Classroom Undergraduate Courses \\
\hline PFUAB & PPC Special Program for Distance Undergraduate Courses \\
\hline PPCMTER & $\begin{array}{r}\text { Professional Master's Degree in Networked Educational } \\
\text { Technology }\end{array}$ \\
\hline PPCGP & Project of Classroom Educational Management \\
\hline PPCGUAB & Project of Distance Education Management \\
\hline PPCPPGE & Project of Master's Degree and PhD in Education \\
\hline
\end{tabular}

The detailed and categorical analysis process of this timeline led to the final interpretation of categories such as: curricular activities (focusing on teacher performance) and technological and pedagogical fluency (focusing on integration of networked educational technologies and convergence of teaching mode). Considering this categorization, a survey ${ }^{1}$ questionnaire was elaborated for professors working in undergraduate and postgraduate courses of CE/UFSM and for students of these courses. From a total of 2349 students, 223 filled the questionnaire, and from 170 professors, 26 did. The data obtained from the questionnaires were submitted to statistical analysis, in the free software $R^{2}$, and tested for clustering ${ }^{3}$, in order to group the responses given.

The emergent categories of the official documents studied were taken as the guiding line for the elaboration of the questionnaire. The questions were therefore elaborated from this categorization, in order to verify if the school practices and the educational context converged for the promotion of public policies. Thus, it aimed to analyze how the guidelines and parameters of public policies are effectively manifested in the PPP and educational practices in the CE / UFSM.

After the questionnaire was elaborated, we implemented it with a group of research professors and students of the institution, in order to evaluate its coherence with the research theme and its relevance in the educational field. Subsequently, the questionnaire was implemented to the large group of teachers and students of the CE I UFSM. It should be noted that the validation participants' answers did not count as analysis data. In addition to this process, the presentation of the research problem and its justification to the teachers and students participating in the action research was also implemented as a validation act

The student questionnaire has 20 multiple choice sentences, with alternatives arranged in Likert ${ }^{4}$ scale of five points following the order of 1 to full disagreement until 5 to full agreement. Besides the 20 sentences, there was also descriptive space for additional comments and/or suggestions. The instrument for professors is composed of a total of 23 sentences in the same Likert scale. They were applied from November 16 to December 122015.

\section{Results and Discussion}

The analysis of the results derives from the triangulation as a methodological strategy, intertwining data from the PPC, the public policies and graphic images (cluster

Dialogical relations between public educational policies and technological-pedagogical fluency in teacher training. Elena Maria Mallmann y Juliana Sales Jacques 
analysis, factor analysis) of the survey questionnaires. This analysis combines "different methods of different research approaches in qualitative research" seeking "triangulation to expand the knowledge of a topic or to evaluate results mutually" (Flick, 2009, p. 90-91).

\subsection{Curricular Activities}

Curricular activities for the integration of networked educational technologies, essential for the improvement of technological and pedagogical fluency, are not explicitly addressed in all PPC. The projects use different terms to guide educational practices, and hybridize teaching and learning spaces. Curricular activities in the PPC are understood as actions and operations as teacher's participation in the production of knowledge inside and outside the classroom and/or virtual spaces. Curricular activities integrate and compose teaching performance and are developed based on the understanding that each teacher/professor has on the role of all of those involved in the process. Thus,

The participation of teachers in the process of knowledge production, not only in regards to education issues, but also in research and extension, is the means by which knowledge can be improved and renewed, in order to have the necessary transformations that education produces as a result. In this case, the teaching action is proposed as a means for training researcher teachers who not only teach, but also research, and undergraduate students certified and trained to assume their roles in the society. (PEED/CE/UFSM).

PEED is alligned with the Law of Directives and Bases of National Education (Lei de Diretrizes e Bases da Educação Nacional - LDB), Law No. 9.394, of December 20, 1996, article 43, item V, on the purpose of higher education, "to arouse the desire for constant cultural and professional improvement and enable the corresponding embodiment, integrating the knowledge being acquired in an intellectual framework that systematizes the knowledge of each generation "(D2_L_96).

The participation of professors and the desire for constant improvement (performance) mentioned in the public policies have broad sense, that is, a sense of "a practice that changes an established order, that modifies it qualitatively and quantitatively", covering, "therefore, all forms of action" (Pereira, 2013, p. 25). The tripod teaching, research and extension is regarded as inseparable action that maximizes the production of knowledge in higher education. It can be envisaged that networked educational technologies can enhance the processes of teaching, research and extension at UFSM to the extent in which the PPC presents the need for improving and renewing the knowledge linked to the process of teacher-researchers training in concrete terms in their texts.

The basis of knowledge construction in most PPC is action-reflection-action focused on the teaching and learning of the curricular contents. This is in agreement with the Resolution CNE/CP1, of February 18, 2002. Research as a building block of knowledge is what Freire's epistemology presupposes, because human beings are imbued in the social, which implies going beyond the interpretation of reality, but changing it. Curricular activities constitute the pedagogical process because the teacher and student performance mediated by technologies can generate critical pedagogical practice that in turn generates new knowledge. Training autonomous Dialogical relations between public educational policies and technological-pedagogical fluency in teacher training. Elena Maria Mallmann y Juliana Sales Jacques 
teachers, critical and creative in the "interpretation, invention and (re)construction of reality" is central to PEEN / CE / UFSM. In the PPC analyzed, knowledge is supported theoretically, and, at the same time, built from the different world views.

By sharing the same understanding, the discourse materialized in the PFP show the need for critical-reflective curricular activities because they provide "investigative practices that promote the qualification of the teaching-learning process, enabling the deepening of knowledge that is inherent to the complexity of the socio-cultural context that encompasses the daily educational space in which they will enter professionally" (PFP). The purpose is to train teachers to research their own practice. The improvement of technological and pedagogical fluency is essential to problematize the reality they in; intervene in and transform it. It is intended, therefore, to educate teachers to assume "the role of subjects of the production of their world intelligence, and not just of recipients of the reality passed on to them" (Freire, 1996, p. 78).

Skills and abilities inherent to the investigative practices are directly related to the integration of educational technologies in the curricular activities, given that the Resolution CNE/CP1 of February 18, 2002, article 2, states that each institution should include, in the curricular organization, guidance and training for teaching activities, including the preparation for " $\mathrm{VI}$ - the use of information and communication technologies, and of innovative methodologies, strategies and supporting materials" (D2_R1_02).

In this regard, in the questionnaires, the evaluation of professors points that the infrastructure of UFSM is not sufficient for the integration of educational technologies in the curricular activities in teacher training courses (Figure 4).

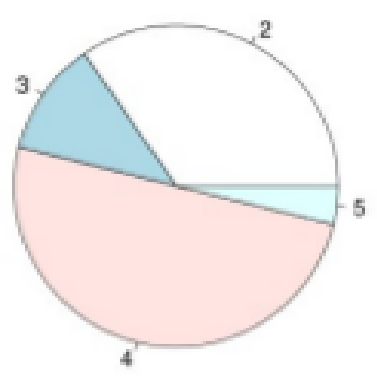

Figure 4: Teachers' position on UFSM's infrastructure for the integration of technologies Source: The authors. Graph generated from the questionnaire implemented.

There is a high concentration of responses in alternative 4 - partly agree. Option 2 partly disagree - is less predominant, but prevails over the other two alternatives. It is inferred, therefore, that at the same time that the university already provides resources for the integration of technology, professors may not know the institutional and national support policies for the promotion of technological and pedagogical fluency. By not knowing the conception of integrating technologies in school practices, one ends up charging the institution itself for its absence or limitation.

In contrast, the infrastructure herein mentioned may be related to issues of the very centers to which professors are linked. Morphologically, the word infrastructure is a combination of infra + structure. Both words are derived from Latin: infra - means

Dialogical relations between public educational policies and technological-pedagogical fluency in teacher training. Elena Maria Mallmann y Juliana Sales Jacques 
internal, inside; structura - means, based on different fields of knowledge, a manner to build, organize, a system of relations among groups of people. In this sense, the curricular activities in this infrastructure may not encompass the integration of technologies as one of its basic actions. Returning to the document analysis, it is clear that many PPC mention it on a surface level.

By analyzing the data of the questionnaires, it is observed that teachers lack knowledge on educational public policies of support to the integration of technologies. We used the hierarchical technique of Cluster Analysis, with the method based on the distance between the centroids of the groups formed. Through inspection of the dendrogram (Figure 5), only one main group can be identified. The other issues form separate groups.

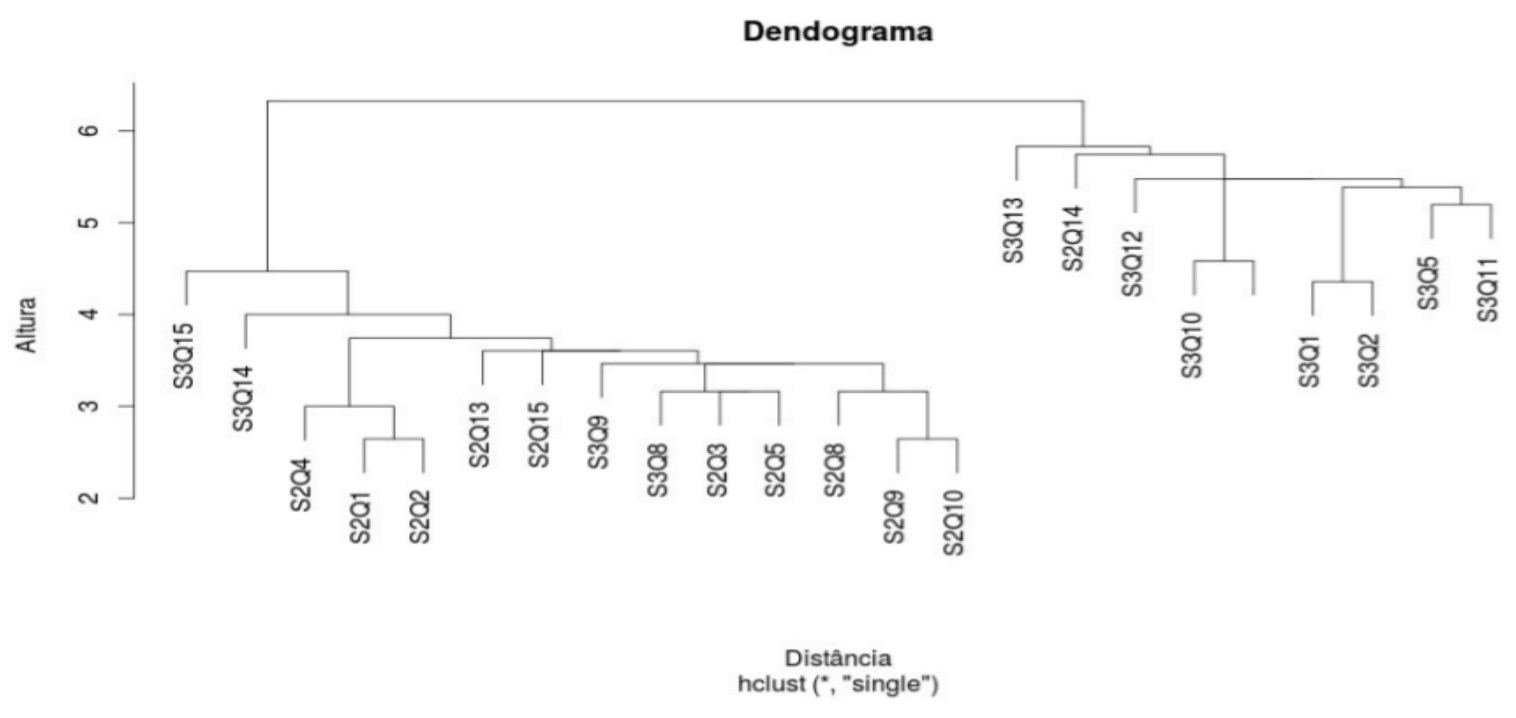

Figure 5: Dendrogram

Source: From the authors

Visually, possible clusters among the issues can be seen (Figure 5). The main group comprises the issues of Figures 6, 7, 8, 9 and 10 with the statements:

Figure 6 - "Public policies and educational projects of teacher training courses provide sufficient guidance for the integration of educational technologies";

Figure 7 - "Students of the courses in which I work know the public policies towards the integration of educational technologies in teacher training courses";

Figure 8 - "Public policies that guide the integration of educational technologies in teacher training courses are advertised at UFSM";

Figure 9 - "Technologies for the development of teaching practices in teacher training courses that are available in public portals and repositories are advertised at UFSM";

Figure 10 - "The pedagogical projects of the teacher training courses are up-todate, according to current legislation." 


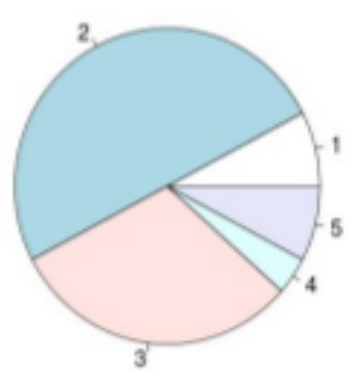

Figure 6: Positioning on PPC Source: The authors. Graph generated from the questionnaire implemented.

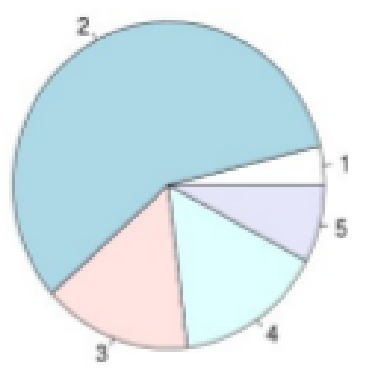

Figure 7: Positioning on the knowledge of the public policies of integration of the technologies Source: The authors. Graph generated from the questionnaire implemented.

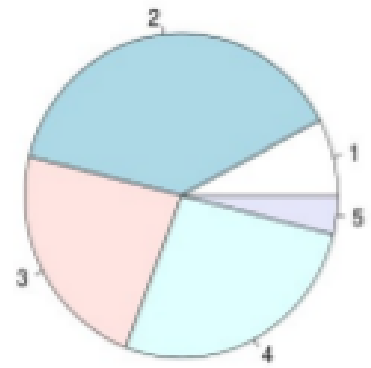

Figure 8: Positioning on the dissemination of public policies for the integration of technologies

Source: The authors. Graph generated from the questionnaire implemented.

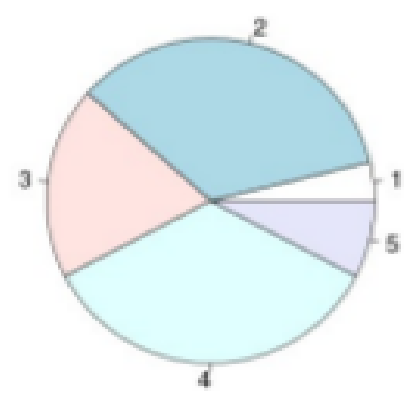

Figure 9: Positioning on the dissemination of technologies to develop school practices

Source: The authors. Graph generated from the questionnaire implemented.

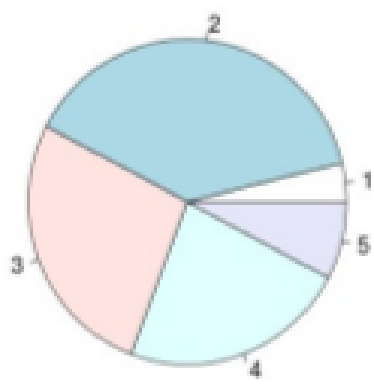

Figure 10: Positioning on PPC upgrade

Source: The authors. Graph generated from the questionnaire implemented.

The questions grouped are those with the highest concentration of responses in alternative 2 - partly disagree. These questions are linked to the issue of infrastructure, as they justify it. This is because, from the partial disagreement with the statement that UFSM offers infrastructure for the integration of technologies, as well as with the questions presented, it is evaluated that:

a) there are weaknesses in the guidelines of public policies and PCC for teacher training in relation to the integration of educational technologies. The propositions in the documents are very general, and do not specify actions and operations necessary for the didactic transposition of content and curricular activities and to take advantage of the potential of technology for the democratization of teaching and learning.

b) public policies that guide the integration of educational technologies are not widely publicized in the CE/UFSM. This requires the institution to develop training, in addition to investing in academic events whose topic is public

Dialogical relations between public educational policies and technological-pedagogical fluency in teacher training. Elena Maria Mallmann y Juliana Sales Jacques 
policies to support the integration of technologies in the curricular activities, and the teaching performance in this context. By investing in advertising, and moving forward to reflection and problematization about what is, how to implement and what the objectives are of the teaching-learning process mediated by technology, the construction of technological and pedagogical fluency is enhanced both to professors and to students in higher education.

\subsection{Technology-pedagogy fluency}

The student and professor performance constitutes and is constituted by curricular activities. Thus, educating professors with skills and competences for teaching requires ability for the planning and development of convergent educational practices in contemporary days. In this scenario, the teaching-learning process needs to establish a relation with the practices experienced by students in real situations, considering that "the social and work relations are increasingly mediated by new media" (Amiel; Do Amaral, 2013, p. 2). We work, we communicate, we share information, as well produce knowledge mediated by networked technologies. Those information, communication and network production mechanisms are present in everyday actions. Therefore, they must be part of the education process.

By integrating technologies and educational practices, innovation, democratization and curricular flexibility are sought. This proposal is covered in the guidance provided by the PFUAB PPC, as it states that the pedagogical practices developed should "offer conditions to build knowledge about and apply information and communication technologies, as well to construct methodologies, strategies, and supporting material towards the innovation of the educational process".

Similarly, the PEEUAB proposes to:

[...] Train teachers online for Special Education, Teaching degrees, and Bachelor's degree, in higher education, to work with Childhood Education and Early Years of Primary Education in the different modes of Special Education, using communication and information technologies in different educational environments.

Both PPC include the integration of technologies as an action that maximizes the innovation in pedagogic practices. Considering an online course, whose teachinglearning process is mediated by networked technologies, it is expected that the PPC emphasizes, in the teaching and learning, the development of technological and pedagogical skills to create teaching and learning situations, making use of the potentials of the networked educational technologies. . But does the fact that this is a distance course, in a Virtual Environment of Teaching and Learning (VETL), make it offer more opportunities for students, when teachers, have "the conditions for knowledge and application" of technologies in the didactic transposition? To what extent does the integration of network technologies in the initial formation interferes in pedagogical practices of graduate teachers?

By relating the categories of analysis, it is possible to say that the pedagogical practices could be propositional for the integration of technologies by the graduate teachers, or not. This is a matter of didactic-pedagogical organization which is based both on teacher training and on epistemological principles and socio-cultural conceptions of each professional, since both are developed and enhanced during the

Dialogical relations between public educational policies and technological-pedagogical fluency in teacher training. Elena Maria Mallmann y Juliana Sales Jacques 
whole life. The action-reflection-action principle, present in the educational public policies for the academic education of teachers, clearly brings this theoretical-practical interface.

The fact that a course is online does not a guarantee that it would develop proper fluency so that future teachers can handle networked technologies in their pedagogical practices. In regards to that, only in one of the PPC analysed is this subject discussed as proper curricular content. In addition to the integration of networked educational technologies on students' actions and operations for knowledge appropriation, it is necessary that investments are made on the development of technological-pedagogical fluency. Students need to operate the technologies, understanding their potentials on the teaching-learning process. If this comprehension is built, it is possible to transcend the understanding from meaning (integration of networked technologies conceptually defined) to sense perception (meaning mediated by a pedagogical conception) and contextual evidence.

The performance is supported by epistemological basis and pedagogical theories appropriated by teachers/professors during their training and practice. The methods of organization and development of the curricular contents (integrating technology or not) are directly related to the conception built. In a critical-performative pedagogy view, convergent to a Freire's libertarian pedagogy, Pineau (2013, p. 40) argues that "critical educators consolidate their convictions in concrete commitments, both in the political and in the educational sphere". The educational practice mediated by technologies is rooted in the epistemological, political and ideological principles that constitute education. The performative teaching practice is the materialization of these principles.

The guidelines of PPD are in compliance with the argumentative structure of this analysis, by proposing that the module Information and Communication Technologies Applied to Education (ICT), along with the other modules of the curriculum, is worked so as to foster knowledge appropriation to create teaching-learning situations (supported by investigative practice in teaching), using the potentials of ICT.

By analyzing the proposal of a module, in a teacher training course aiming to integrate technologies in pedagogical practices, that can be considered an advance for Higher Education Institutions (HEI), in terms of public policies implementation and curricular innovation. It seeks, however, that the integration of networked technology pervades all curriculum components, or, going beyond, the curricula of (initial and continuing) teacher training courses since their creation, aligned with the design of educational strategies and infrastructure.

While this integration requires teachers to develop skills to go beyond knowledge to make use of networked technologies, it also requires students to develop actions and operations inherent to the process of knowledge appropriation. In this sense, learning occurs collaboratively. That is, teachers and students share knowledge that optimizes the construction of their fluency in networked technologies. We are not here arguing that the teacher should rely on improvisation at work, in fact it is quite the contrary. Because we defend that technology fluency is essential for didactic transposition, we argue that the pedagogical practices need to be planned and mediated by the teacher so that students also develop their fluency. The sharing aforementioned refers to the feasible and possible solutions to the extreme situations faced during the teachinglearning process mediated by networked technologies.

Following the analysis of the PPC, it is observed an emphasis on skills development for

Dialogical relations between public educational policies and technological-pedagogical fluency in teacher training. Elena Maria Mallmann y Juliana Sales Jacques

Página 10 de 16 
the integration of technologies both in initial training and in the pedagogical practices of teachers who graduate by the program, what constitutes the continuum construction of technological and pedagogical fluency:

Identify and propose the development of methodologies for the use of information and communication technologies in educational practices involving specialized care in Special Education. (PEEN/CE/UFSM).

Provide other forms of construction of knowledge through media and technologies, such as teleconferencing, videoconferencing, and tools provided by the platform to be used by the course. (PEEUAB/CE/UFSM)

Also, the PPGGUAB implies training activities for the development of fluency, by mentioning that the tutors selected to work in the course modules should have at least an initial classroom and distance training, and seek the appropriation of basic notions, both technological (environment, tools, software, etc.) and pedagogical (in regards to their performance, the dynamics of the methodologies and strategies, etc.). These notions are necessary for tutors to be able to propose actions aiming to build knowledge and overcome the difficulties that may emerge in the interaction in an online learning community. (PPGGUAB/CE/UFSM).

In the interpretive-critical context here designed, the technological and pedagogical fluency relates to knowing how to integrate networked technologies both in the field of technology (knowing the tool and how to handle it in its various versions) and teaching (transposing knowledge by making use of the potentials of technology, producing collaboratively, and sharing their productions in a network). The concept derives from studies based on Schneider's conceptions (2012) as well as Kafai et al. (1999).

While the first author brings the concept of technological fluency as the development of technical, practical and emancipatory levels, the second authors approach it (though not naming it fluency, but skills in technologies) as the development of contemporary skills, basic concepts and intellectual capacities.

By establishing relations between the conceptions studied, and due to the movement of action-reflection-action afforded by research, discussion and analyses, the concept of technological and pedagogical fluency emerged, defined by Mallmann, Schnneider and Mazzardo (2013, p. 5, emphasis of the authors) as:

[...] the ability to mediate the teaching-learning process with knowledge about planning, methodological strategies, content, teaching materials, networked educational technologies with focus on VETL, actions with students to challenge, discuss, problematize, and instigate reflection and criticism, encourage interaction with the group and with the environment and materials, the development of collaborative work, autonomy, authoring and co-authoring, emancipation, monitor the study and implementation of the students' activities by identifying problems and proposing solutions, maintain good communication with the ones involved in the process in the online environment, reflect on the pedagogical potential of the resources used, educational practices implemented and on

Dialogical relations between public educational policies and technological-pedagogical fluency in teacher training. Elena Maria Mallmann y Juliana Sales Jacques Página 11 de 16 


\section{performance itself.}

Considering the problematizing dialogue as a basis - essence of fluency -, it is possible to analyze the proportion of each response in the graph generated from the questionnaire answered by professors in relation to the following statement: "Students develop interaction between themselves and the professor mediated by educational technologies in the curricular and extracurricular activities of the course" (Figure 11). A relation of the answers obtained by students was established for the following sentence: "When I have doubts about the curricular activities, I interact with professors and classmates mediated by the educational technologies available at UFSM" (Figure 12).

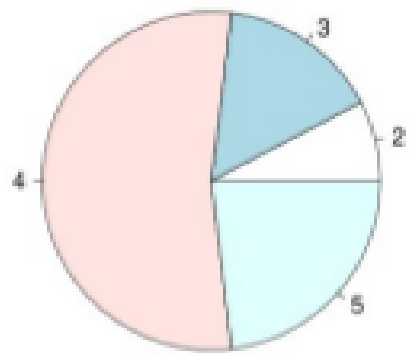

Figure 11: Positioning on technologymediated interaction in curricular and extracurricular activities

Source: The authors. Graph generated from the questionnaire implemented.

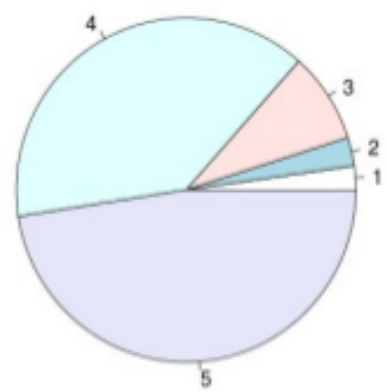

Figure 12: Positioning on technologymediated interaction to solve doubts Source: The authors. Graph generated from the questionnaire implemented.

Figure 11 shows a higher concentration of answers in alternative 4 - partly agree. It is also close to alternative 5 - completely agree. Figure 12, however, the highest concentration of answers relies on alternative 5 - completely agree, even though there is a significant probability of answers on alternative 4 - partly agree. This result allows us to infer that the dialogue pervades the performance of professors and students in regards to curricular activities. Nevertheless, it is necessary to consider the partiality of the answers. Also, there is a considerable proportion in relation to alternative $3-1$ neither agree nor disagree - , what causes some concern, as this result, considered in relation to the others, demonstrate different problematizations:

a) the interaction provided to and experienced by professors and students in the curricular activities does not generate the necessary conditions to foster the technological-pedagogical fluency in the teaching-learning process;

b) the interaction is seen as simple communication, whose focus is the emission and reception of information, and, as a result, does not generate the transformation effect required on the teaching-learning process;

c) the students do not take active roles on knowledge construction;

d) there is a need for advances in the construction of the technologicalpedagogical fluency of both professors and students, so that both become authors and co-authors, through collaboration grounded on interaction, emancipating themselves as autonomous subjects that problematize and assign new meanings to their performance.

Dialogical relations between public educational policies and technological-pedagogical fluency in teacher training. Elena Maria Mallmann y Juliana Sales Jacques Página 12 de 16 
Hence, technological and pedagogical fluency is an essential construction for teaching performance. Ths is because, considering the theoretical thinking here proposed, the didactic transposition is based on the problematizing dialogue as a means to transform the wise knowledge into teaching knowledge. In order to make use of technology to transpose knowledge in the perspective that considers the teaching and learning process, in addition to the technological knowledge to access technology, handle it according to its updates, and integrate hypermedia, it is necessary to understand the concept of the teaching-learning process and regard it as fundamental for pedagogical practices. That implies planning and developing pedagogical practices in which the teaching-learning process is mutual between teacher and students, focused on problem-solving and based on action-reflection-action.

\section{Conclusion: why media education in higher education?}

The results suggest that there is still a deficit on the integration of technologies in pedagogical practices of teacher training courses, even though some of the PPCs present curricular guidelines. In online courses, there are wider guidelines in public policies and PPCs related to the integration of educational technologies, as they develop a major role for the process of communication.

For teacher and students to have a clear comprehension of their responsibilities and possibilities with the integration of educational technologies, it is essential that technological and pedagogical fluency is developed, considering that it allows the appropriation of resources and tools for didactic and methodological innovations, enabling greater flexibility to perform activities and, consequently, for the construction of new knowledge.

Therefore, the integration of networked technologies is necessary to make the actions of teaching and learning more democratic, flexible and innovative. Media education in higher education is an urgent debate in Brazil, considering the international expansion of non-formal education policies (http://publications.jrc.ec.europa.eu/repository/bitstream/JRC96968/ifna27660enn.pdf). The existence of an environment with favorable technological and pedagogical conditions is important for students to develop individual and collaborative study activities, to establish a critical dialogue with classmates and professors. Moreover, by interacting with curricular content and by interaction itself, it is expected that students internalize and systematize information, producing knowledge and applying it to their context.

This is clearly related to the formative role of public policies and PPCs, and, mainly, to the tasks of a team responsible for the elaboration of documents that are consistent with the current demands of public policies, the community attending the courses, as well the group of teachers or professors responsible for their implementation. Based on in loco results, it is clear that the integration of networked educational technologies in teacher training needs to be encouraged and problematized in official documents. Furthermore, public policies need to establish a more straightforward writing in its texts, so as to determine, with the necessary flexibility, the priority axes of pedagogical and technological innovation. University professors and researchers of networked educational technologies need to participate in the productive movement (evaluation and cyclic deliberation) of public policies so that these aspects are covered and the demands are met.

Dialogical relations between public educational policies and technological-pedagogical fluency in teacher training. Elena Maria Mallmann y Juliana Sales Jacques 


\section{Notes}

1 It is a tool for information acquisition about characteristics, actions or opinions of a great number of people representing a population (Tanur apud Pinsonneault, Kraemer, 1993, p. 6).

$2 R$ is a free software for statistical computing and graphics. $R$ is an oficial parto f Free Software Foundation, project GNU 's, and of R Foundations, with similar objectives to the other principles of open source softwares, such Apache Foundation or GNOME Foundation. (http://goo.gl/RNob)

3 Clustering is the creation of classes, sub-sets of registers that represent the closest values in particupar attributes, producing a scheme of clusters that splits a set of data into classes (Castro, 2003, p. 6).

4 Likert scales requires respondents to indicate a degree of agreement or disagreement to statements regarding the attitude measured. Numeric value and/or signs are attributed to the responses to reflect the strength and direction of the reaction of the respondent to the statement. (Brandalise, 2005, p.4)

Presentación del artículo: 10 de junio de 2017 Fecha de aprobación: 15 de junio de 2017 Fecha de publicación: 30 de junio de 2017

Mallmann, E.M., y Jacques, J.S. (2017). Dialogical relations between public educational policies and technological-pedagogical fluency in teacher training. RED, Revista de Educación a Distancia, 54. Consultado el (dd/mm/aaaa) en http://www.um.es/ead/red/54

\section{FUNDING}

This paper is included within the research project titled Tecnologias Educacionais em Rede na Formação Inicial e Continuada de Professores: impacto das políticas públicas nas práticas escolares, recognized and funded by Conselho Nacional de Desenvolvimento Científico e Tecnológico (CNPq) e Coordenação de Aperfeiçoamento de Pessoal de Nível Superior (CAPES).

\section{References}

Amiel, T. \& Do Amaral, S. F. (2013). Nativos e Imigrantes: Questionando o conceito de fluência tecnológica docente. Revista Brasileira de Informática na Educação, V. 21, N. 3.

DOI: http://dx.doi.org/10.5753/RBIE.2013.21.03.1

Brandalise, L. T. (2005) Modelos de medição de percepção e comportamento - uma revisão. UNOESTE. Disponível em: <https://goo.gl/vUWv2H>.

Brasil. Leis, Etc; Cury, C. R. J. (2003). Lei de diretrizes e bases da educação (Lei 9.394/96). DP \& A.

Brasil. (2004) Ministério da Educação. Conselho Nacional de Educação. Portaria № 4059, de 10 de dezembro de 2004.

Dialogical relations between public educational policies and technological-pedagogical fluency in teacher training. Elena Maria Mallmann y Juliana Sales Jacques 
Brasil. (2014). Ministério da Educação. Universidade Federal de Santa Maria. Projeto Pedagógico do Curso de Graduação Licenciatura em Pedagogia a Distância. Disponível em:

$<\mathrm{http}: /$ w3.ufsm.br/pedagogiaead/index.php?option=com_content\&view=article\&id=46\&ltemid $=113>$.

Brasil. (2006) Ministério da Educação. Universidade Federal de Santa Maria. Projeto Pedagógico do Curso de Graduação Licenciatura em Pedagogia Presencial diurno. Disponível em: <https://portal.ufsm.br/ementario/curso.html?idCurso=1061 >.

Brasil. (2006) Ministério da Educação. Universidade Federal de Santa Maria. Projeto Pedagógico do Curso de Graduação Licenciatura em Pedagogia Presencial noturno.

Brasil. (2014).Ministério da Educação. Universidade Federal de Santa Maria. Projeto Pedagógico do Curso de Graduação Licenciatura em Educação Especial a Distância.

Brasil. (1981). Ministério da Educação. Universidade Federal de Santa Maria. Projeto Pedagógico do Curso de Graduação Licenciatura em Educação Especial Presencial diurno.

Brasil. (2009). Ministério da Educação. Universidade Federal de Santa Maria. Projeto Pedagógico do Curso de Graduação Licenciatura em Educação Especial Presencial noturno.

Brasil. (2007). Ministério da Educação. Universidade Federal de Santa Maria. Projeto Pedagógico do Programa Especial de Graduação (PEG) - Formação de Professores para a Educação Profissional a distância. Disponível em: <https://ead08.proj.ufsm.br/moodle2_UAB/mod/folder/view.php?id=44175>.

Brasil. (2012). Ministério da Educação. Universidade Federal de Santa Maria. Projeto Pedagógico do Programa Especial de Graduação (PEG) - Formação de

Professores para a Educação Profissional Presencial. Disponível em: <http://w3.ufsm.br/peg/index.php/home/noticias/22-projeto-pedagogico-do-curso-ppc>.

Brasil.. (2012). Ministério da Educação. Universidade Federal de Santa Maria. Projeto Pedagógico do Curso de Pós-Graduação em Gestão Educacional a Distância. Disponível em:

<http://coral.ufsm.br/gestaoeducacionalead/images/PROJETO_GESTO_EAD_-_2012.pdf>.

Brasil. (2006). Ministério da Educação. Universidade Federal de Santa Maria. Projeto Pedagógico do Curso de Pós-Graduação em Gestão Educacional Presencial. Disponível $\quad$ em: <http://w3.ufsm.br/espgestao/?page_id=87>.

Brasil. (2012). Ministério da Educação. Universidade Federal de Santa Maria. Projeto Pedagógico do Curso de Mestrado Profissional em Tecnologias Educacionais em Rede. Disponível em: <http://coral.ufsm.br/ppgter/index.php/2015-04-29-14-4541/projeto-politico-pedagogico>.

Brasil. (2014). Ministério da Educação. Universidade Federal de Santa Maria. Projeto Pedagógico do Curso do Programa de Pós-Graduação em Educação. 2012.

Dialogical relations between public educational policies and technological-pedagogical fluency in teacher training. Elena Maria Mallmann y Juliana Sales Jacques 
Disponível em: <http://coral.ufsm.br/ppge/index.php/institucional/ppp>

Castro, M. A. T. A. (2003). Projecto Agrupamento - "Clustering". ISEP - Instituto Superior de Engenharia do Porto DEI - Departamento de Engenharia Informática. Portugal.

Dalmolin, A. M. T. (2014). Extensão universitária na Unipampa Campus Alegrete: a construção de elos Entre comunicação-intenção. Dissertação (Mestrado em educação), Universidade Federal de Santa Maria, Santa Maria, 128 p.

Flick, U. (2009). Qualidade na pesquisa qualitativa. Porto Alegre: Artmed.

FREIRE, Paulo. (1996). Pedagogia da autonomia: saberes necessários à prática educativa. São Paulo: Paz e Terra.

Freire, P. (1987). Pedagogia do oprimido. 17. ed. Rio de Janeiro: Paz e Terra.

Kafai, Y. et al. (1999). Being fluent with information technology. Disponível em: $<\mathrm{http}: / / g 00 . g / / w s \times 3 d k>$.

Mallmann, E. M.; Schneider, D. R.; Mazzardo, M. D. (2013). Fluência tecnológicopedagógica (FTP) dos tutores. Novas Tecnologias na Educação, v. 11 No 3, dezembro, 2013. CINTED/UFRGS, Porto Alegre. DOI: http://dx.doi.org/10.5902/198464443978

Moraes, R.; Galiazzi, M. C. (2006). Análise textual discursiva: Processo reconstrutivo de múltiplas faces. Ciência \& Educação, v. 12, n. 1, p. 117-128. DOI: http://dx.doi.org/10.1590/S1516-73132006000100009.

Pereira, M. de A. (2013). Performance docente: sentidos e implicações pedagógicas. Pereira, M. de A. (org.). Performance e Educação: (des)territorializações pedagógicas. Santa Maria: Ed. da UFSM.

Pineau, E. L. (2013). Pedagogia Crítico-performativa: encarnando a política da educação libertadora. In: Performance e Educação: (des)territorializações pedagógicas. Pereira, M. de A. (org.). Santa Maria: Ed. da UFSM.

Pinsonneault, A.; Kraemer, K. L. (1993). Survey research in management informationsystems: An Assessment. ). I.T. in Government, Center for Research on Information Technology and Organizations, UC Irvine. Disponível em: <http://goo.gl/Rm56Gz>.

Schneider, D. da R. (2012). Prática dialógico-problematizadora dos tutores na UAB/UFSM: fluência tecnológica no Moodle. Dissertação (Mestrado em educação), Universidade Federal de Santa Maria, Santa Maria, 204 p. 